DOI: https://doi.org/10.47405/mjssh.v5i6.411

\begin{tabular}{|c|c|}
\hline 1. 1.54 & Malaysian Journal of Social Sciences and Humanities (MJSSH) \\
\hline $\begin{array}{c}\text { Malaysian Journal of } \\
\text { solal sciences and }\end{array}$ & Volume 5, Issue 6, June 2020 \\
\hline (MJ-SSH) & e-ISSN : 2504-8562 \\
\hline & $\begin{array}{l}\text { Journal home page: } \\
\text { www.msocialsciences.com }\end{array}$ \\
\hline
\end{tabular}

\title{
Urban Sprawl: Environmental Consequence of Rapid Urban Expansion
}

\author{
Ibimilua Adewale Festus ${ }^{1}$, Ibimilua Foyeke Omoboye ${ }^{2}$, Ogundare Babatope Andrew ${ }^{2}$ \\ 1Department of Geography and Planning Science, Faculty of the Social Sciences, \\ Ekiti State University, Ado-Ekiti, Ekiti State, Nigeria \\ 2Department of Geography, School of Arts and Social Sciences, College of Education, \\ Ikere-Ekiti, Ekiti State, Nigeria
}

Correspondence: Ibimilua Adewale Festus (wibimilua@yahoo.com)

\begin{abstract}
Urban Sprawl is a disturbing issue to geographers, urban planners and allied professionals in the $21^{\text {st }}$ century. The anxiety is based mainly on the social, political, economic, cultural and environmental consequences of rapid urban growth. Hence, this study examines the reasons for urbanization, as well as encroachment of urban development into the border belt. Next, the study probes into the causes, consequences and adverse effects of uncontrolled infringement and conversion of rural land to urban uses. Likewise, the study investigates the processes of land use development, population expansion and physical growth, as well as their ecological foot prints. Consequently, the study identified the major causes of urban sprawl as rapid population increase, high level of urban development pressure, provision of housing, changes in living standard, as well as technological changes among others. Also, the study found out that urban sprawl is desirable because of the benefits of spread of development, low rent at the periphery, as well as lesser pressure on the environment of the border belt. Also, the effects of urban sprawl were recognized as destruction of the means of livelihood of the rural dwellers at the urban fringe belt, land fragmentation, food scarcity, changes in the ecosystem, environmental pollution, biodiversity loss, as well as loss of wildlife habitat. For the achievement of sustainable urban development in the $21^{\text {st }}$ century and beyond, the study recommends environmental monitoring with the aid of geographic information systems and remote sensing techniques, environmental impact assessment, development control, farm land policy, regulation of land allocation, sustainable land use management, as well as enforcement of planning policies.
\end{abstract}

Keywords: development, environment, encroachment, sprawl, sustainability, urbanization

\section{Introduction}

The proportion of the world's population between rural and urban areas is changing fast. Globally, the proportion of people living in cities rose from about $30 \%$ in 1950 to $47 \%$ in 2000 , and is projected to reach $61 \%$ by 2030 (McNeely, Redford \& Carter, 2005). People are moving from rural areas to urban centres due to centrifugal forces in rural areas and centripetal pressures in urban centres. This movement, coupled with urban-urban migration, and international migration (immigration) among other factors are responsible for urbanization. The factors that are influencing further urban growth include improvement in transportation, social change, natural urban growth, tertiary activities, as well as industrialization. 
Urban centres are noted for possibility of employment opportunities, performance of central place function for rural areas, innovation diffusion, production of goods for rural and urban dwellers, as well as trickling down effect to suburbs and adjoining rural areas. Closely associated with the rapid growth of the world population in general and that of the Third World in particular is the rapid growth of the urban population (Onokerhoraye, 1995). Urban population across the globe is growing at an alarming rate. Consequently, urban expansion is posing unprecedented challenges to man and his environment. Among the confrontations are large scale unemployment, inadequate social and infrastructural amenities, crime and delinquency, traffic congestion, shortage of housing, as well as high cost of living. Invariably, in order to escape from many of these challenges, people move to the fringe belt of urban centres. This process of migration of people from high density areas to low density areas and the subsequent abandonment of the city centre for the periphery is known as urban sprawl.

Urban Sprawl is one of the problems in the cities nowadays (Habibi\&Asadi, 2011). The term was coined by a city planner named Earle Draper in SE US in the year 1973. The term urban sprawl (also known as sprawl or suburban sprawl) refers to the process through which natural areas give way to built-up areas and new highways constructed, and old roads being upgraded for the easy movement of people to and fro the urban centre. Urban sprawl is a product of unrestricted growth in the suburbs of urban centres mainly as a result of little consideration for urban and regional planning. It occurs in form of spreading of development to the fringe belt as against clustering together in the urban core area.

The term urban sprawl is used in urban and regional planning to depict the growth pattern of cities from the high density core area to the low compactness suburb. Development is patchy, scattered and strung out, with a tendency for discontinuity (Habibi\&Asadi, 2011). In order words, urban sprawl refers to low density residential development. It is characterized by low density residential housing, increased reliance on private automobiles for transportation, uncoordinated growth, mixed use development, haphazard development, inefficient design, poor services, as well as land use and land cover changes. In some cities, urban sprawls are accompanied by the development of shanty settlements at the suburban fringe (Sada, 1970 quoted in Aderamo, 2000).

The issue of urban sprawl has been a serious concern across the world (see Pendal, 1999; Brueckner, 2000; Habibi\&Asadi, 2011; Rubenstein, 2012; Botkin\& Keller, 2012; George, 2002). Urban and regional planners, architects, surveyors, academics, politicians and policy makers are interested in the causes, consequences and remedies to urban sprawl. Researchers have argued that sprawls can help us to reshape urban landscape (Mohsen, Helmi, Noordin, Biswajeet\&Shabeh, 2014; Downs, 1999; Gordon \& Richardson, 2000). Urban sprawl helps to control land prices. It makes inner city housing to become cheaper, as a result of the filtering of high income earners to the suburb. It prevents urban congestion and it improves the quality of life. In all, urban sprawl has positive ecological, environmental, social, economic and community foot prints.

On the other hand, there are many negative effects of urban sprawl on man and his environment. It affects the environment, government, economy and quality of life negatively. The environmental impacts of urban sprawl include degradation of water quality, loss of wildlife, and habitats, loss of agricultural land, loss of natural landscape, as well as shift in energy resources use. Also, the impacts of urban sprawl on quality of life include lesser physical activities, higher vehicular ownership, higher driving mileages, more highway fatalities, as well as greater health risk. Other serious negative effects of urban sprawl are destruction of unique natural areas, stratospheric ozone depletion, climate change, and degradation, and discouragement of production in agriculture. The word sprawl is used because the perimeters of the city have simply been extended outward into the countryside, one development after the next, with little plan as to where the expansion is going and no notion as to where it will stop (Wright \&Boorse, 2015). Overall, urban sprawl emanates from the problems in the urban core areas that make people to move to the outskirt of the city. Such problems include poor housing, inadequate water supply, inefficient urban waste management, traffic problem, environmental pollution, as well as urban decay. Nevertheless, urban sprawl becomes an issue to environmentalists and other stake holders because of its impact on the economy, government, biodiversity, environment, ecological system, as well as the future of urban centres. 
Addressing urban sprawl requires environmental education, community action, encouragement of smart growth, citizen participation in urban planning, private-public partnership in planning, preservation of natural resources, as well as urban renewal. Cheam \&Ong (2018) submitted that making difference to the environment requires environmental awareness, education, attitude, and management. These are the precautionary motives for the protection and conservation of the environment. Unfortunately however, insufficient funds, weak enforcement of environmental and planning laws, as well as technological problems are the challenges towards the control of urban sprawl.

\section{Urbanization}

There are so many definitions, percetions and arguments about the meaning, causes, consequences and remedial measures to urbanization (see Rebelle, 1994; Kiran, 2019; Hick, 1974; Blair, 1975; Jay, 2001; Sanni, Adewoyin, Bako\&Akande, 2018; Botkin\& Keller 2012; Hu, Yuan \&Fucal, 2017; United Nations, 2001). The term refers to increase in population and expansion of settlement. Urbanization began in ancient Mesopotamia in the Uruk period (4300-3100 BCE). It connotes an increase in the percentage and in the number of people living in urban settlements (Rubenstein, 2012). Viewed from the perspective of Urban and Regional Planning, Oyesiku (2010) defined urbanization as the population of a country's (or region's) total population living in places classified as urban. Hence, he submitted that the degree of urbanization varies according to the percentage of the total population that are living in urban centres. Again, Williams Brunn\&Darden (1983), quoted in Oyesiku, 2010 described urbanization process as the movement of people from rural to urban places and the concomitant changes in the life style of the people including values, attitudes, and behaviours.

Elliot (1989) offered a more comprehensive overview and analysis of urbanization when he perceived it as a complex and continuous movement of people from rural to urban areas. Thus, he opined that urbanization is the creation of new patterns of living and the communication of these new patterns to both urban and rural populations. In another development, Rana (2013) perceived urbanization as a process leading to social change, characterized by the movement of people from rural to urban areas. It is one of the indicators of socio-economic transformation and economic development (Oyesiku, 2010).

The major functions of settlements are some of the factors that are responsible for urbanization. These include administrative, commercial, ecclesiastics, cultural, market, industrial, as well as resorts. Others include the presence of port, military zone, recreational and tourism facilities, as well as developed transportation system. Hence, the factors that aid urbanization include prevailing economic activities, population growth, influence of central authority, social influence, as well as peace and security. Rural-urban migration is a major cause of urbanization. It is the process of urban development under which mass migration of people from rural areas to industrialised urban areas, take place, due to increased job opportunities (Garg, 2010).

Researches have also confirmed that urbanization is caused by population growth, administrative status, alteration in land uses and changes in land cover, as well as anthropogenic activities (see United Nations, 2001; Mohamed \&Doaa, 2016; Struss, 1961; Paul, 2000; Sada, 1973; Onokerhoraye, 1995) previous studies have also revealed that the search for better way of living, natural increase in birth rate, quest for employment opportunities, exploration for higher education, as well as demand for recreation and tourism activities are other causes of urbanization (see Paul, 2000; Kiram, 2010; Jay, 2001, Sada, 1973; Struss, 1961; United Nations, 2001; Wright \&Boorse, 2015; George, 2002). In other words, urbanization occurs as a result of the pull to the urban centre, as well as the push from the rural areas. In all, the factors that are responsible for urbanization can be summarized as physical, economic, historical, religious, political, as well as location advantages.

Urbanization is usually seen with negative connotations but it has so many positive effects (see Downs, 1999; Gordon \& Richardson, 2000; Frica, 2019; Sanni et. al. 2018; Jay, 2001; Blair 1874; Kiran, 2019). It is as a major catalyst to economic development, and it is an activator to industrial 
growth. The major prospects of urbanization include increase in labour force, large source of market, propensity for increment in investment and productivity, diversity talents and skills, as well as attraction of foreign aids (Ibimilua\&Ibimilua, 2020). In spite of its numerous advantages, urbanization has socio-economic and psychological challenges. There is hardly any region of the world without some problems of city growth and development (Oyesiku, 2020). The problems of urbanization include unemployment, pressure on social amenities, shortage of housing, increase in crime rate, high cost of living, and reduction in standard of living. Urbanization is also associated with inadequate urban open spaces and recreation parks, environmental degradation, solid waste generation and management, poor sanitation, as well as disfiguration of landscape. Urbanization is also responsible for depopulation of rural areas and depression of rural areas. Above all, Garg (2010) opined that urbanization is responsible for depletion of resources, environmental pollution, climate change, as well as biodiversity loss.

Several remedial measures have been propounded for the problems of urbanization they include the formulation and proper implmenetation of master plan, enforcement of development control, implementation of urban and housing programmes, as well as involvement of relevant professionals in urban and regional planning. Solving the problems of urbanization require combating poverty, pollution abatement, provision of housing, as well as sustainable solid waste management. Other remedial measures are urban employment generation, urban land use management, flood and erosion control, urban population growth control, pollution control and management, upgrading of slums and squatter settlements, as well as social development policy.

\section{Causes Of Urban Sprawl}

Researches have confirmed that many factors are responsible for urban sprawl (see Downs 1999; Pendall, 1999; Bhatta, 2010; Sudhira, Ramachandra\&Jagadish, 2004; Bruekner, 2000). Major causes of urban sprawl are associated with the problems that are peculiar to urban core areas which force people to the outskirt of the urban centres. These factors include the high incidence of crime and violence at the urban core areas, environmental pollution, quest for serenic environment, housing problem and soft escape from human congestion. Other problems that warrant urban sprawl are parking problems, accidents, traffic congestion, as well as environmental degradation. George (2002) noted that major causes of urban sprawl are rapid population growth, easier and cheaper accommodation for migrants, as well as inadequate monitoring and control of development. She noted further that physical expansion usually start along major transport corridors before it expands to inner areas. She opined further that such areas are usually characterized by inadequate drainage system and extensive flooding.

According to her (George, 2002), physical expansion is inevitable because land and accommodation are easier and cheaper to acquire at the urban fringe belt. She declared further that urban sprawl is more rampant along transportation corridors. People are compelled to move to the outskirt of cities as a result of the high value of land at the city centre, pressure of several environmental problems at the city centre, poor condition of housing in the city centre, lower tax rate, as well as quest for privacy. In his own perspective, Aderamo (2000) opined that unguided growth of urban centres usually lead to disorderly development. He opined further that rapid growth of urban population results in the expansion of the physical component of towns. He concluded that urban sprawls emanate from the inability of urban government to sufficiently supply urban services.

Urban sprawls are associated with low density scattered settlements, discontinuous construction, spread of development into agricultural area or extension of city into the countryside. Urban sprawl refers to the extent of urbanization, which is a global phenomenon mainly driven by population growth and large scale migration (Sudhira et. al., 2004). Also, to Paul (2000), urban sprawls are caused by continued demand for housing. He declared further that urban sprawl develop without planning and unchecked growth. In essence, urban sprawls are motivated by population increase, economic growth, globalization, as well as lower land rates. Several authors had focused on changes in standard of living, lifestyle choices or consumer preferences as major causes of urban sprawl (see Mohsen et. al., 
2014; Brueckner, 2000; Habibi\&Agadi, 2011; Pendall, 1999; George, 2002; Bhatta, 2010). From many of these studies, empirical evidences have shown that people tend to move to the periphery of cities for large homes, more bedrooms, bigger balconies, as well as desire for increased living space.

Studies have also confirmed that urban sprawls are also influenced by uncontrolled physical expansion, political decision, infertility of soil, poor sales of farm produce, as well as land fragmentation. Historical evidences have proved that the factors that aided urban sprawl include housing boom, highway construction and industrial revolution among others. In all, urban sprawl is expedited by rural-urban migration, rapid population increase, congestion in the city centre, as well as pressure on social and infrastructural amenities. Other factors are technical changes, level of commercial activities, level of industrialization, urban development pressure, housing constraint, attractive land and housing prices, as well as weak planning laws.

\section{Impact Of Urban Sprawl}

Several studies had focused on the positive and negative impacts of urban sprawl (Pendall, 1999; Gordon \& Richardson, 2000; Brueckner, 2000; Downs, 1999; Mohsen et. at., 2014). From these studies, empirical evidence has accumulated, focusing mainly on the repercussions. However, urban sprawl has short term and long term aftermaths. Empirical literatures have revealed that notable cities across the world have benefited from urban sprawl. Examples include Shanghai, London, New Delhi and Paris to mention a few. Urban expansion is quite desirable. It is a stupendous reliever to the pressure at the city centre. It is responsible for structural change in the environment. It increases the geographic extend of cities, keeps housing affordable, reduces crime rate, depresses noise pollution, moderates traffic and other urban problems. It makes residents to enjoy more yard space. For short, urban sprawl is a good development for controlling the challenges in urban centres.

Urban sprawl causes depopulation of urban centres, and reduces the pressure on the core areas of cities. It serves as support for industries, tourism, as well as science and traditional knowledge. It has positive impact on land use development, population expansion and physical growth. It serves as creator of employment opportunities for construction (site) workers, generator of revenue (in form of property tax) to the government, as well as agent to opening up of new areas. Apart from serving as support for tourism, science and traditional knowledge, urban sprawl has social, cultural, psychological and ecological foot prints. Urban sprawl has several negative impacts. These include economic, social, political, environmental and psychological implications. The counteractiveimpact of urban sprawl include disruption of ecosystem services, reduction in ecosystem complexity and diversity, as well as changes in biogeochemical cycles. It is responsible for food scarcity, loss of natural resources forfeiture of soil fertility, land degradation, damage to energy resources, depletion of forest wealth, degradation of biodiversity, as well as pollution of the environment. Additionally, urban sprawl is a major cause of fresh water degradation, deforestation, biodiversity loss, land degradation, as well as stratospheric ozone depletion. It leads to unauthorizeddevelopment, non-conformity with master plan, encroachment into agricultural land, as well as conversion of productive farmland into industrial, residential and other non-agricultural landuses.

Researches have shown that urban sprawl is the major cause of land fragmentation, encroachment on the source of raw materials, depletion of natural resources, loss of farm labour, discouragement of farmers, threat to sustainable agricultural practices, as well as food shortage (see Sudhira et. al. 2004; Mohsen et. al. 2014; Brueckner, 2000; Bhatta, 2010). The environmental impact of urban sprawl include loss of wildlife, destruction to wildlife habitat and species, threat to sustainable ecotourism, environmental pollution, as well as global warming. Other negative consequences of urban sprawl are increased car dependency, damage to cars because of bad roads, health issues, increased energy use, high cost of services, ineffective land use control, uncontrolled growth, as well as decline in community distinctiveness. 


\section{Literature Review}

A large empirical literature exists on the meaning, causes, process, characteristics, effects and control of urban sprawl (see Rubenstein, 2012; Wright \&Boorse, 2015; George, 2002; Mohsen et. al., 2014; Pendell, 1999, Brueckner, 2000; Habibi\&Asadi, 2011). Most of the studies revealed that urbanization is the major cause of urban sprawl. Ibimilua and Ibimilua (2020) perceived urbanization as the process of transformation of a settlement from rural status to urban eminence. They explained that urbanization is caused by the push from the countryside and pull to the city. Where, the pull factor includes market potentials, industrialization, social amenities, increased services activities, and cultural attractions. The push factors include poverty, unemployment and neglect. Urbanization is a necessary step in the inevitable trend of modern and social development that promotes industrial structural adjustment (Hu, Yuan, Zhou \&Fucal, 2017).

Ibimilua\&Ibimilua (2020) submitted that urbanization is desirable. They identified the prospects of (urbanization) as increased labour force, large source of market, diversity of talent, as well as reduction of pressure on rural land. On the other hand, urbanization is associated with problems like environmental degradation, social vices, and economic problems. Also, it creates physical, political, ecological and psychological challenges. Some of them are increased demand for housing, solid waste generation and management, unemployment, traffic congestion, pressure on available social and infrastructural amenities, growth of slums and squatter settlements as well as poor standard of living. Other problems are high cost of living, poor housing condition, health challenges, social instability, as well as administrative disequilibria (see Frica, 2019 for greater details). Urbanization changes the green, wet and earthen land to the sterile concrete and asphalt paved land (Garg, 2010). It is equally responsible for ecological and environmental issues like urban flood, pollution of all types, disfiguration of landscape, ozone depletion, acid rain and climate change.

Habibi\&Asadi (2011) noted that when urban growth is more than usual, its pressure on the boundaries and city will face new major problems. In their survey of some sprawled cities, they found out that in the urbanized areas of New York, Chicago in (USA); Spain and Portugal (in Europe); Zangjan and Beinjing (in Asia), social, economic, and demographic factors are responsible for urban sprawl. They identified the major causes of urban sprawl(in the identified cities) as increasing income, cheaper price of land, more space per person, private car ownership, as well as bigger apartments at the outskirt of cities. On the other hand, they identified the predicaments that are associated with urban sprawl as lack of open spaces, social problems as well as inadequate public facilities and infrastructural amenities.

Rubenstein (2010) perceived urban sprawl as the development of new housing sites at relatively low density and at locations that are not contiguous to the existing built-up area. He recognized urban sprawl as the progressive spread of development over the landscape. He itemized the attractions in urban sprawl as detached single-family dwelling rather than a row house or apartment, private land surrounding the house, space to park several cars at no cost, greater opportunity for home ownership, as well as private retreat from the stress of urban living. He explained further that urban sprawl offers more space for play and protection from high crime rates and that heavy traffic characterize the city centres. Nevertheless, Rubenstein (2012) identified the major problems with urban sprawl as social segregation, inefficiency, displeasing aesthetics, as well as haphazard and uncoordinated development.

Researches have revealed that urban sprawl could be desirable if it is well managed (see Pendall, 1999; Habibi\&Asadi, 2011; Mohsen et. al. 2014). It could help in reducing the pressures that are associated with urban core areas and blightedness. The strategies of enhancing livable urban sprawl include the provision of varieties of transportation choices to enhance the movement of people, control of physical development, as well as creation of open spaces and facilities for recreation and tourism. Other strategies include the mixture of different land uses (commercial, institutional, industrial, circulation, and residential) in order to make the environment more enabling, conducive and attractive for human habitation. The reasons for the control of development in urban sprawls are strategic, economic, social, planning, as well political consideration. Similarly, the constraints to development 
control at the urban sprawl areas include policy implementation, social and economic conflicts, political influences, as well as inadequacy of regional plans.

\section{Conclusion}

The issue of urban sprawl is a concern to many stakeholders in urban and regional planning. Urban sprawl is a product of urbanization. It is perceived as a means of soft escape from the troubles that are associated with the urban core areas. Nevertheless, urban sprawls are characterized by poorly planned urban development. It is usually confronted with the challenges of environmental pollution, poor sanitation, high rate of crime and anti-social behaviours, traffic jam, poor quality of housing, health predicament, as well as poor waste disposal system. These problems force urban dwellers to move to the outskirt of the city. This process of encroachment of urban centres into agricultural land is called urban sprawl. The benefits that are associated with urban sprawl include materials and economic growth, job opportunities, diffusion of ideas, as well as cultural diversity.

In spite of the numerous positive effects of urban sprawl, it has negative consequences on agriculture, topography, wildlife, vegetation, climate, water table, as well as anthropogenic activities. Hence, for the achievement of sustainable cities, this study recommends the execution of master plans, urban development control, implementation of urban housing programmes, meaningful planning and coordination, as well as prohibition of development beyond defined areas. Other recommended measures are smart growth, environmental education, citizen participation, efficient urban management, sustainable land management, as well as environmental monitoring through the application of modern techniques like Geographic Information System, Aerial Photo Interpretation, Remote Sensing, as well as Global Positioning System.

\section{Recommendations}

Getting rid of urban sprawl is somehow difficult. However, reducing its negative impacts requires the collaborative efforts of the government, non-governmental organizations, individuals, and other stakeholders in urban planning and management. It depends upon the involvement and participation of many professionals (like urban planners, architects, surveyors, ecologists, municipal engineers and estate managers) in city planning and management. Combating urban sprawl should incorporate the application of geo-information technology in development control. Such techniques include the application of remote sensing, aerial photography, land use/land cover classification and evaluation, cadastral mapping, as well as geospatial information and disaster management techniques. Controlling urban sprawl entails effective urban administration, implementation of urban land use master plans, development control, pollution abatement, conservation of biodiversity, rural development, as well as creation of new towns. Other strategies are greening of landscape, development of good transportation system, provision of low income housing, poverty alleviation, and environmental quality monitoring.

Sustainable solutions to urban sprawl include effective urban management, development control, effective urban governance, establishment of new towns, preparation and implementation of master plans, housing finance, provision of infrastructure, provision of employment, as well as supplying of housing loan. For the attainment of smart and sustainable cities that are devoid of unguided development, 'building up' should be encouraged instead of sprawling. Moreover, development of urban growth boundaries beyond which construction is restricted is a strategy of controlling urban sprawl. Other measures are conservation of natural resources at the fringe belt, strong implementation of planning laws and regulations, as well as the use of appropriate technology in harnessing environmental resources.

In order to make life meaningful for urban sprawl dwellers, there should be provision of recreation facilities, control of urban population growth through family planning, public enlightenment, sustainable waste management, enforcement of environmental protection and conservation acts, as well as citizens participation in urban planning and management. Curtailing urban sprawl should 
encompass the creation of green belts, rehabilitation of existing roads and construction of new ones, provision of private gardens, as well as landscape planning. Above all, in order to reduce the influx of people from city centres to suburban, and the consequent suburban sprawl, there should be improvement of urban conditions through urban redevelopment, rehabilitation and repair of old buildings in inner cities, as well as strict enforcement of Environmental Impact Assessment (EIA) and Environmental Cost Benefit Analysis (ECBA).

\section{References}

Aderamo, A. J. (2000). City Planning and Management Techniques. In H. I.Jimoh\& I. P. Ifabiyi (eds.). Contemporary Issues in Environmental Studies. Ilorin, Hatee Press \& Publishing Co. Ltd.

Bhatta, B. (2010). Analysis of Urban Growth and Sprawl from Remote Sensing Data. Canada, Springer.

Blair, T. L. (1974). The International Urban Crisis.New York, Hill and Wang.

Botkin, D. B. \& Keller, E. A. (2012). Environmental Science ( $8^{\text {th }}$ edition), New Jersey, John Wiley \& Sons Inc.

Brueckner, J. K. (2000). Urban Sprawl: Diagnosis and Remedies. International Regional Science Review, 23 (1) 160-171.

Cheam, C. L. \&Ong, S. C. (2018).Making Difference to the Environment: Understanding Undergraduates' Environmental Behaviour, Malaysian Journal of Social Sciences and Humanities. 3 (1) 1-13.

Downs, A. (1999). Some Realities About Urban Sprawl and Urban Decline. Housing Policy Debate. 10 (4) 955-973.

Elliot, J. M. (1998) Urban Society. Connecticut, USA. Dushkin Publishing Group Inc.

Elmes, A. \& Mitchell, C. J. A. (2020) Counterurbanites and Commercial Landscape Change in the Canadian Countryside: Insights from Paris, Ontario. The Journal of Rural and Community Development. 15 (1) 49-70.

Frica, E. A. K. (2019). Social Welfare of Urban Communities in Residential Areas.Malaysian Journal of Social Sciences and Humanities. 4 (6) 181-196,

Garg, S. K. (2010). Ecology and Environmental Studies.New Delhi, Khanna Publishers.

Garg, S. K. \&Garg.R. (2008).Environmental Studies and Technology.New Delhi, Khanna Publishers.

George, C. K. (2002). Basic Principles and Methods of Urban and Regional Planning.Lagos, LibroGem Books.

Gordon, P. \& Richardson, H. (2000).Critiquing Sprawl's Critics.Policy Analysis.365, 1-18

Habibi, S. \&Asadi, N. (2011).Causes, Results and Methods of Controlling Urban Sprawl.Procedia Engineering. 21 (1) 133-141.

Habitat (1999). The Habitat Agenda.Nairobi, Kenya, Habitat.

Hick, U. K. (1974). The Large City: A World Problem. London, Macmillan.

Hu, M.; Yuan, J.; Zhou, Z. \&Fucal, L. (2017). Relationships Between Urbanization, Economic Growth, Industrial Structure and Nitrogen Emissions in the Jishui River Basin Based on a VAR Model. Saudi Journal of Humanitie and Social Sciences. 2 (2) 144-151.

Ibimilua, F. O. \&Ibimilua, A. F. (2020). Urban Slums: Environmental Sustainability at a Cross Road.Saudi Journal of Humanities and Social Sciences. 5 (3) 172-176.

Jay, M. (2001).Cities at Risk Habitat Debate. 7 (4) 1-4.

Kiran, M. (2010).Bringing Hope to the Slum.Footsteps. 83 (1) 14-15.

McNeely, J. A.; Redford, K. H. \& Carter, A. S. (2005). A Taxonomy of Support: How and Why New Constituencies are Supporting Protected Areas. In J. A. McNeely (ed.). Friends of Life.New Partners in Support of Protected Areas.Gland, Zwitzerland and Cambridge, IUCN.

Mohamed, A. I. \& DOGG, M. M. (2016).Smart Cities and Sustainability.A Set of Vertical Solutions for Managing Resources.International Journal of Environment and Sustainability. 5 (3) 1-15

Onokerhoraye, A. G. (1995). Urbanization and Environment in Nigeria: Implications for Sustainable Development. Benin City. The Benin Social Science Series for Africa.University of Benin.

Oyesiku, K. (2010). New Cities in Urban and Regional Development Planning. Lagos, Longman.

Paul, G. (2000). Mastering Geography. London, Macmillan. 
Pendall, R. (1999). Do Land Use Control Cause Urban Sprawl? Environment and Planning. 26 (1) 555-571.

Rana, S.V.S. (2013). Essentials of Ecology and Environmental Science. New Delhi, PHI Learning Private Limited.

Rebele, F. (1994).Urban Ecology and Special Features of Urban Ecosystems.Global Ecology and Biogeography Letters. 4 (6) 173-187.

Rubenstein, J. M. (2012). Contemporary Human Geography.Nw Delhi, PHI Learning Private Limited.

Sada, P. O. (1973). Urbanization Trend and Problems of Urban Administration in Nigeria. In A. Adebayo \& L. Rowland (eds.). Management Problems of Rapid Urbanization in Nigeria.Ile-Ife, University of Ile-Ife press.

Sanni, L. K.; Adewoyin, Y.; Bako, A. I. S. \&Akande, O. S. (2018).Urban Crime Prevention and Adaptation Measures in Ilorin, Nigeria.Tanzania Journal of Development Studies. 16 (2) 32-48.

Sudhira, H. S., Ramachandra, T. V. \&Jagadish, K. S. (2004). Urban Sprawl: Metrics, Dynamics and Modelling Using GIS. International Journal of Applied Earth Observation and Geoinformation. 9 (1) 29-39.

Struss, A. (1961). Image of American Cities. New York, Free Press.

United Nation (UN) (2001). The State of the World's Cities.Istambul, Habitat Publication Unit.

Williams, J. F.; Brunn, D. S..; \& Darden, J. T. (1983).World Urban Development. In S. D. Brunn\& J. F. Williams (eds) Cities of the World-World Regional Urban Development. New York, Harper and Row.Pp. 3-42

Wright, R. \&Boorse, D. F. (2015). Environmental Science: Towards a Sustainable Future. India, Pearson. 